\title{
CAVES, STORIES, HISTORY AND POPULAR TRADITIONS IN THE SEMI-DESERT (SERTÃO) OF BAHIA, NORTHEASTERN BRAZIL
}

\author{
JAME, ZGODBE, ZGODOVINA IN LJUDSKO IZROČILO V \\ POLPUŠČAVI (SERTÃO) BAHIA, SEVEROVZHODNA BRAZILIJA
}

\author{
Elvis Pereira BARBOSA ${ }^{1} \&$ Luiz Eduardo Panisset TRAVASSOS ${ }^{2}$
}

\begin{abstract}
UDC 553.4(569.5)

Elvis Pereira Barbosa \& Luiz Eduardo Panisset Travassos: Caves, stories, history and popular traditions in the semi-desert (sertão) of Bahia, northeastern Brazil

The symbiosis between man and caves usually causes a mixture of fascination and respect. When looking back at the history of Antique civilizations, there are references to this relationship made in almost all cases. Caves were men's first home, their first meeting places, shelters, and ritualistic places. Nowadays, even with the fear of darkness and closed areas that is so usual, that old-time connection still exists. In the contemporary world, some places still hold a special sacred meaning to many social groups. Thus, the pilgrimage to Mecca in Saudi Arabia, to the shrine of Fatima in Portugal, to the Ganges River in India or to the cave church of Bom Jesus da Lapa in the interior of Bahia State, Brazil, are closely related when it comes to spiritual complicity. These sites play a key role as a collective reference of human sacrifice in an increasingly automated, technical and individualistic world much more than as strengthers of the religious faith. In Brazil there are many important religious sites. This paper mentions important sites specifically from the northeastern region. The examples are the Sanctuary of Bom Jesus da Lapa, the Cave of Patamuté, the Brejões Cave, and the Milagrosa Cave. All these examples show clear manifestations of popular traditions and year after year illustrate the important roles that caves play in regional Brazilian societies. This paper is not intended to diminish the physical studies of karst areas but it wants to emphasize the importance of the human variable, especially in developing countries, for the relationship between karst and caves in the popular tradition, transmitted by means of oral stories and folk beliefs goes beyond the scientific advances.
\end{abstract}

Keywords: folk beliefs, religion, pilgrimages, caves, northeastern Brazil.
Izvleček

UDK 553.4(569.5)

Elvis Pereira Barbosa \& Luiz Eduardo Panisset Travassos: Jame, zgodbe, zgodovina in ljudsko izročilo $v$ polpuščavi (sertão) Bahia, severovzhodna Brazilija

Simbioza med človekom in jamami navadno povzroča mešanico očarljivosti in spoštovanja. Ko se oziramo v zgodovino antičnih civilizacij, se skoraj v vseh primerih zapiski sklicujejo na te odnose. Jame so bile človeška prva domovanja, mesta srečevanj, zavetij ter ritualistični kraji. Danes, kljub strahu pred temo in zaprtimi prostori, ki je tako nenavaden, nekdanja povezava še vedno obstaja. V sodobnem svetu mnoge socialne skupine nekaterim krajem še vedno pripisujejo poseben sveti pomen. Tako so romanja v Meko v Savdsko Arabijo, k svetišču Fatime na Portugalskem, k reki Ganges v Indiji ali v jamsko cerkev Bom Jesus de Lapa v notranjosti države Bahia v Braziliji tesno povezana $\mathrm{v}$ smislu duhovne sokrivde. Našteta območja igrajo ključno vlogo kot kolektivna referenca za človeško žrtvovanje v vedno bolj avtomatičnem, tehničnem in sebičnem svetu, mnogo bolj kot ojačevalci verskega zaupanja. V Braziliji je mnogo pomembnih verskih krajev. Ta članek omenja pomembne kraje posebno v severovzhodni regiji. Ti so svetišče Bom Jesus de Lapa, jame Patamuté, Brejões in Milagrosa. Vsi ti primeri kažejo jasno prikazovanje ljudskega izročila in leto za letom slikajo pomembno vlogo, ki jo imajo jame v regionalnih brazilskih družbah. Namen tega članka ni zmanjšati fizične študije kraških pokrajin, ampak poudariti pomen človeka, še posebej $v$ razvijajočih se državah. Pomembno je tudi za odnos med krasom in jamami v ljudskem izročilu, prenesenem s pomočjo ustnih zgodb ter ljudskih verovanj, ki segajo onstran znanstvenega napredka.

Ključne besede: ljudska prepričanja, religija, romanja, jame, severovzhodna Brazilija.

\footnotetext{
${ }^{1}$ Santa Cruz State University - UESC, Ilhéus (BA), Brazil. Professor of Introduction to Archaeology. Coordinator of the Archaeology Research Group of Bahia - NEPAB/DFCH /UESC. E-mail: elvisb@uesc.br

${ }^{2}$ Member of the Environmental Studies Laboratory, PUC Minas University, Belo Horizonte, Brazil. Coordinator of the section of History of Speleology - Brazilian Speleological Society. E-mail: luizepanisset@gmail.com.br; luizpanisset@uol.com.br
}

Received/Prejeto: 01.10.2008 


\section{INTRODUCTION}

A few years ago, in a Conference organized by the Brazilian Speleological Society (SBE-Sociedade Brasileira de Espeleologia), papers on the importance of caves to people who inhabit their surroundings were still lacking in quantity. Until that moment, little had been produced, in the speleological circles related to the interactions between men and caves and its symbolic aspects. Yet, it was clear that the discussion of the importance of the human usage of kasrt areas was about to come. At that time, the introduction of a new term to designate the approaches of anthropological studies - etnospeleology - was even proposed.
At the conferences and meetings that followed, other researchers also noticed that the speleological circles were continuously repetitive and dealt with the same themes and approaches, such as the topographic and geological aspects of certain caves, always with the same technical data and not cosidering the human usage of the sites. It is known that these approaches are certainly very important; however, the relationship between man and cave, which goes back to the beginning of mankind on Earth, was either left out or neglected by Brazilian speleologists and some of the researches never really focused on human activities, such as rock paintings or pilgrimages near these areas.

\section{ABOUT CAVES AND MYTHS}

The symbiosis between man and caves usually causes a mixture of fascination and respect. When looking back at the history of Antique civilizations, there are references to this relationship made in almost all cases. Primarily, in the Pre-History Era, then in Ancient Greece, Ancient Rome, the Pre-Colombian civilizations and many others.

The pre-historic period of mankind was lived near caves, which were more than a collective space to develop their traditions or their imagination, but understood as the environment that offers protection to humans above all. They were men's first home, their first meeting places and shelters. Nowadays, even with the fear of darkness and closed areas that is so usual, that old-time connection still exists.

It is in the Classical Antiquity that a greater proximity between caves and men can be found as well as the following elements related to them: shadows, darkness and hell. Commelin (1993) shows that the relationship between caves and the Greeks will later influence the history of the western hemisphere. Due to the fact that the Greek philosophers used to live in karst areas, with plenty of caves, the association between darkness (the Night) and the initial idea of hell (through the figure of Erebus) and caves is so intense. Later in this article, however, as we shall see that not all people have the same definition of the concepts shadows, darkness and hell.

It all starts in the Greek mythology: the oldest goddess, Night, was considered to be the goddess of darkness, daughter of Chaos, and some poets designated it the daughter of Heaven and Earth. Hesiod qualified it as one of the Titans and called it Mother of the Gods, because it has always been believed that the Night and Darkness preceded all things. Erebus was considered to be the son of Chaos, brother and husband of the Night, father of Eather and the Day. He was also transformed into a river that rushed into hell for having helped the Titans.

By concentrating firstly on the Greek conception of shadows and darkness, it is observed that this fragile relationship moves progressively towards the conception of a cave being the entrance to a world opposite to that which is found on the surface. According to Commelin $(1993,187)$, hell is an underground site where souls descend to after death. For the Greeks, the door to hell was located in the caves near the Cape Tenaro or Tainaro, in the south of the Peloponnese.

The Greek mythology offers several stories that refer directly to the universe of caves or the underground. The journey of Theseus to the Kingdom of Hades was made to kidnap his wife. When his mission failed, Theseus became a prisoner of Hades being later freed by Heracles, who entered Earth's womb to rescue him. At the end, he returned to the world of the living also through a cave mouth.

Commelin $(1999,198)$ states that in Thessaly and other different regions of Greece, lots of caves were said to be the one from which Hercules brought Cerberus from hell. This monster was the dog with three heads which guarded the entrance of the Kingdom of Hades. According to the common belief or the most widespread popular legend, it was in a cave near the Cape Tenaro, that Cerberus was brought by his dominator in chains, 
with the heads low. In memory of this victory, a temple was erected to Hercules in this place.

The Kingdom of Hades (Pluto in the Roman mythology) was mistakenly acknowledged as hell simply because it was under the ground, a fact which is related to the Christian influence on the Roman literature after Constantine made Catholicism official.

A meaningful part of the Greek mythology is intrinsically related to caves, either due to the myths that supposedly inhabited these places or because of the legends that have been created around them. The Greek gods represented the man and the elements of nature and their fear of the known and the unknown. In other words, the unknown fascinate and stimulate people just for having different characteristics from what is well known. In this context, the unusual is the cave and its surroundings.

In the underground world light normally does not penetrate far into the system, thus allowing a constant state of Chaos. The permanence of this apparent chaos has to do with the lack of reference to determine where the floor and the roof are. Consequently, where both heaven and hell are in such a place where eternal darkness rules, usually dominates popular (folk) imagination especially in a world that is full of religiosity.

All these elements lead us to a broader discussion about the role of caves in the development of human relationship that goes beyond the debate of their ancient meaning, moving towards the understanding of other elements that make up a cave (e.g. the meaning of darkness, of the shadows and hell) for the common people. Without a clear understanding of these elements and how they came to populate the human mind, it will not be easy to understand some actions involving human social groups, karst areas, the cave environment and the consequences of these interactions.

Even when we know that the discussion about these three elements - darkness, shadows and hell - is quite long and not the subject of this paper, we can say that, depending on the social group where the cave is near, the most expressive concept of hell (popularized in the western hemisphere) is related to a very dark and shadowy place even though not all societies share the same exact meaning.

Thus, under the religious perspective, especially the Christian one, hell is literally seen as the end for those who were not good people during their lives. In his masterpiece The Divine Comedy, Dante Alighieri provided a magnificent description of hell locating it in the Earth's core. Among some eastern societies there is no concept of hell, but simply a material level - where men are located - and the immaterial one, which houses gods and deities. But for some people, the cave continues to live on the imaginary as the house of the gods or refuge from normal daily life.

According to Campbell $(1994,181)$, it was mentioned in Ancient India that the days would be terribly hot, the nights would be cold, there would be plenty of diseases and chastity would end. Storms would increasingly extinguish the land and at the end, the entire human and animal life, and all seeds and plants would have to seek shelter in the Ganges, in caves and the sea. To the Jains, caves and cataclysms are related and mark the end of one life cycle, featuring the constant renewal or life transformation, the destruction that brings the new, a movement towards a new beginning.

Not only the Greeks and Jains made references that linked the underground world to religion. As it is widely known, at the beginning of Christianity in the Roman Empire, the followers of the new religion used to get together in the catacombs, where they felt more secure. At the same time, they broke up with the ancient references and traditions that linked the Earth's interior to Pluto's place or Hades, in the Greek mythology.

Paradoxically, after the consolidation of Christianity as a hegemonic religion within the Roman Empire, the underground was no longer a safe place but an area dominated by the devil.

As time went by, a change of values was promoted by this new religion. Old accounts in the Bible, Isaiah 2:20, tells us that the Pagan monarchies would break apart and Israel would be saved when men shall cast away their idols of silver, and their idols of gold, which have been made for themselves to worship, to the moles and to the bats (Campbell 1994, 194).

For those who are entering a cave for the first time, the so-called mouth is much more than a simple opening; it is a portal or gateway to a new world, where rats are transformed into bats, where God confined Satan. Accourding to Commelin $(1993,187)$ the creation of these myths results from the need of plausible explanations for what people do not know.

So it would not be wrong to state that caves, myths and religion are intimate connectedly, especially in a country with many poor and illiterate communities. The unknown underground world is presented as something unusual and under this condition the popular/folk imagination finds space to express its own ideas of the fantastic beings that populate this strange universe.

In Brazil, these dark and "unsafe" places became part of the mythical universe of the local population in remote areas far from major urban centers. In this case, the change of paradigm occurs when there is a combination of material convenience and metaphysical necessity to justify that this change is caused by the search for explanation of the unlikely or by the proliferation of 


\section{LOCATION MAP OF SOME IMPORTANTE CAVE-SANCTUARIES IN THE STATES OF BAHIA, GOIAS AND MINAS GERAIS, BRAZIL}

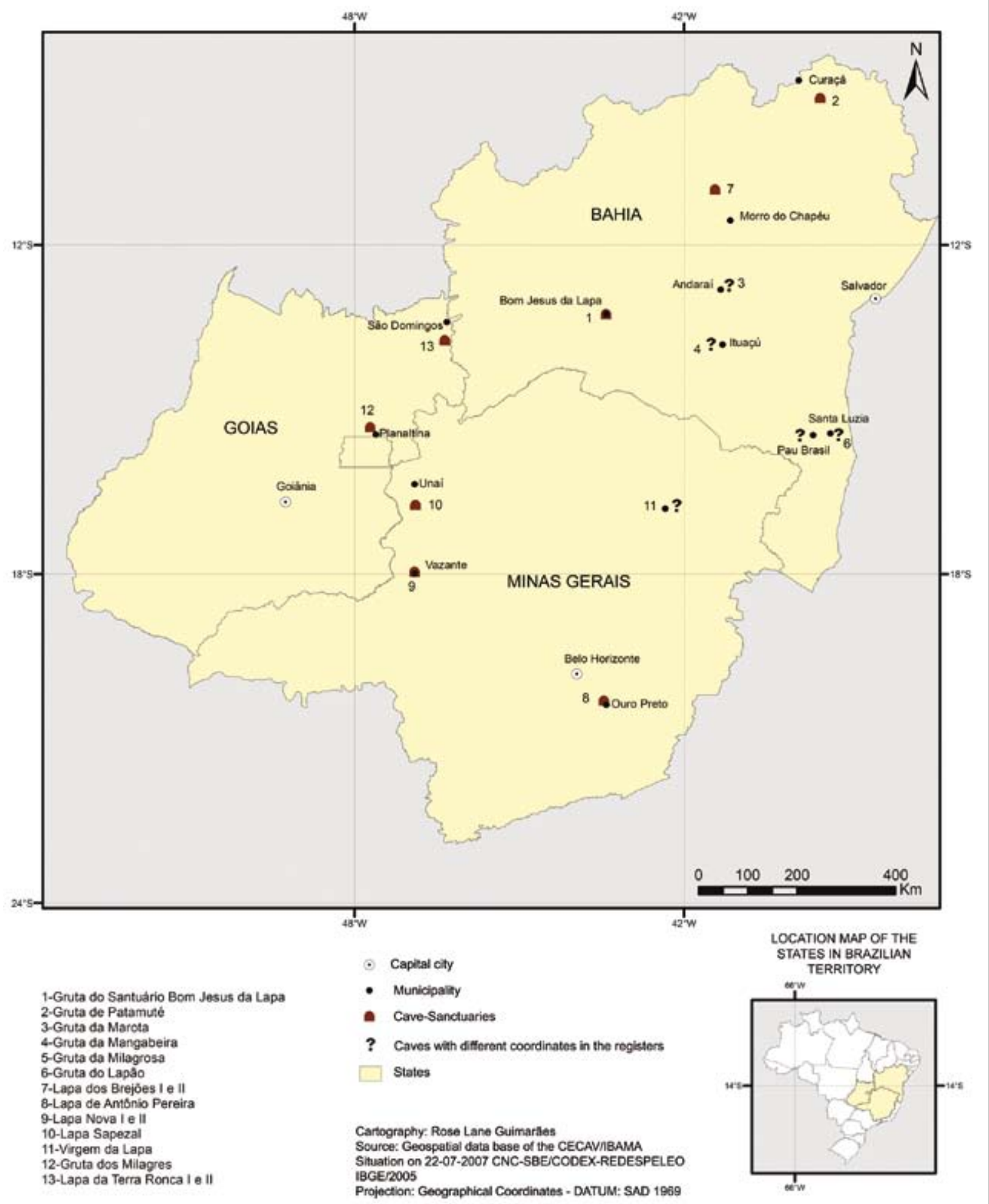

Fig. 1: Location map of some important cave-sanctuaries in Brazil. 
so-called beatified men. To Steil $(1998,36)$, the pilgrimage of these "saint men" and their followers to places distant from their social life seems to be a metaphor to the search of the sacred, which seeks to transcend ordinary time and space through a penitential experience. Then, the caves are no longer places of darkness or the gateway to hell, and are considered to be sacred places where people can feel the presence of God.

\section{CAVES AS SACRED PLACES}

In the contemporary world, some places still hold a special sacred meaning to many social groups. Thus, the pilgrimage to Mecca in Saudi Arabia, to the shrine of Fatima in Portugal, to the Ganges River in India or to the cave church of Bom Jesus da Lapa in the interior of Bahia State, Brazil, are closely related when it comes to spiritual complicity. These sites play a key role as a collective reference to human sacrifice in an increasingly automated, technical and individualistic world much more than as strengthers of the religious faith.

These places are marked by constant pilgrimages throughout the year, especially on the specific dates linked to them. On taking part in a pilgrimage and participating in a collective act of commemoration, an individual can exteriorize his/her faith through the materialization of myths in which this person deposits religious desires. In this sense, nowadays caves represent a connection point between the daily sacrifice and the sacred differently from the type of importance that they had for men at the dawn of civilization.

In Brazil there are many important religious sites. This paper mentions important sites specifically from the northeastern region, where faith sometimes are expressed more vivaciously than other regions. The examples are the Sanctuary of Bom Jesus da Lapa (Fig. 2), located in a municipality with the same name; the Cave of

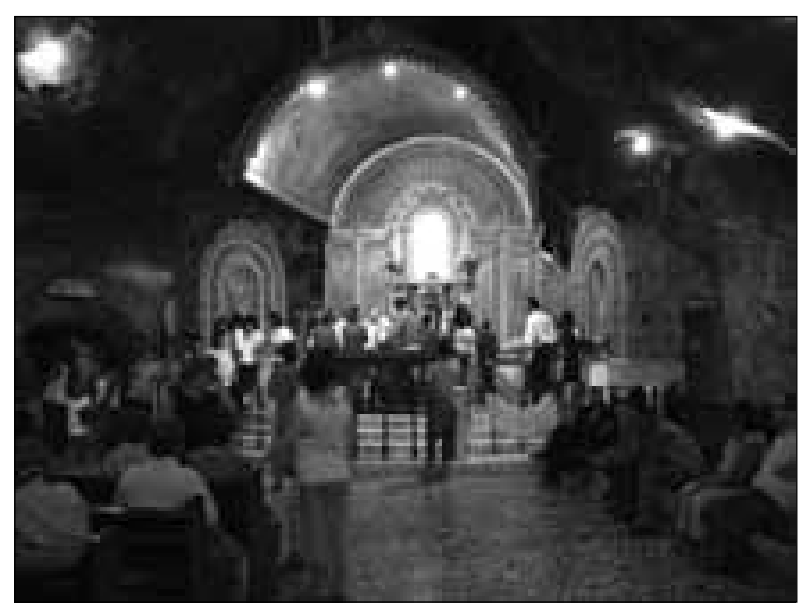

Fig. 2: The main altar of Bom Jesus da Lapa Sanctuary (photo: E.P. Barbosa).
Patamuté, also known by pilgrims as the Sacred Heart of Jesus of Patamuté in Curaçá; the Brejões Cave (Fig. 3), in the municipality of Morro do Chapéu, and the Milagrosa Cave (Miracle Cave) in the municipality of Pau Brasil. All these examples show clear manifestations of popular traditions that identify theses dark places as a place for encountering the Creator.

This phenomenon has aroused the curiosity of speleologists and social scientists because the study of these shrines and pilgrimages sites are considered to be an important tool to penetrate more deeply in the popular/folk culture.

The most well know example of cave-churches in Brazil is the Sanctuary of Bom Jesus da Lapa. The pilgrimage has been ocurring for more than three hundred years and several authors have described the effect of the Sanctuary on the lives of those who visit that cave.

According to Sampaio (2002, 137-138), when a visitor enters the cave, the person experiences its extraordinary and exciting atmosphere. The spectator soon enters the darkness seeing the image of the crucified Bom Jesus da Lapa, offering consolation and cure for those who believe and those who have faith. The pilgrim also experiences emotions and look for the miraculous water that slowly drops from de walls and ceilings. Even nonCatholics cannot deny the effect of excitement when one arrives at the Sanctuary of Bom Jesus da Lapa.

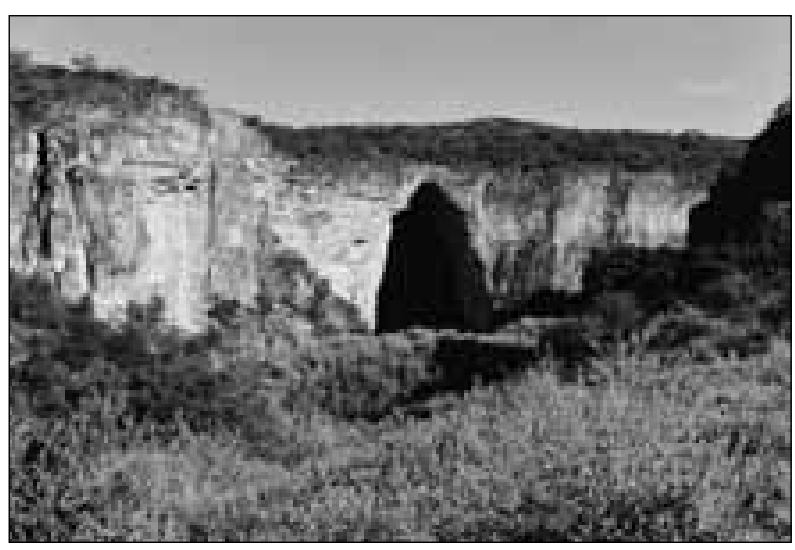

Fig 3: The entrance to the Lapa dos Brejões Cave (photo: E.P. Barbosa). 
Teodoro Sampaio's report is a very detailed one and is the result of his observation of a man who showed his faith and respect in front of the main altar. Besides having both sacred and historical aspects, caves are also linked to mythological elements, a solid ground for real characters to get along with the fantastic imagination of some community groups who live near the places where caves are located. In this context, an informal conversation is believed to be true and sometimes it becomes difficult to make the population accept it as a fictitious or unreal event.

In the interior of Brazil, there are several communities that found caves to be an element of connection between the so-called real world and the sacred entities they believe in, the gods who inhabit and control the existence of the universe. Some of these caves, such as the Cave of Patamuté, located at $90 \mathrm{~km}$ from the nearest city, are far from large urban centers. In other cases they are near urban areas, as it is the case of the Casa dos Loucos Cave (Insane Men Cave) at only $15 \mathrm{~km}$ away from the city. It is interesting to notice that there were objects in the Casa dos Loucos Cave, which were considered to be evidence that Brazilian-African rituals were performed there. It is likely that the word louco, which means insane, was used to name this cave due to the prejudice which usually associates madness to theses rituals.

\section{EXAMPLES OF FAITH}

The examples described below were studied by the researchers while participating in pilgrimages.

Located at about $18 \mathrm{~km}$ from the Patamute municipality, the Sagrado Coração de Jesus Cave (Sacred Heart of Jesus Cave) has all the characteristics of a regular catholic temple. According to Pimentel (1999), the cave is inserted in phyllits, slates and limestone. The cave surroundings display semi-desert vegetation, a characteristic of the Caatinga Fitogeographic Domain, capable of surviving the extreme droughts that occur between the months of October and March. In economic terms, the municipality raises goats, subsistence crops and some agro-industrial plantations.

It is to a harsh environment that thousands of pilgrims come every year to visit the Sagrado Coração de Jesus Cave of Patamuté. The city of approximately 2,000 inhabitants transforms itself from October $30^{\text {th }}$ to November $1^{\text {st }}$, with around 15,000 people that attend the main festival. There are two other small pilgrimages to this cave, one on January 1st and another one on August $6^{\text {th }}$, when a prayer group with over 500 people come from the State of Pernambuco (Cipriano \& Matez 1998, 11).

The cave was accidentally discovery by Zé da Ema, a local hunter who found the cave entrance in the year of 1906 (Cipriano \& Maltez 1998, 9). It is a regional belief that any person who discovers a cave must not tell other people about the finding. If the finder talks about it, he or she will die (Brandão \& Rego 1999). Coincidence or not, Zé da Ema, the discoverer of this cave, died only three months after having announced his discovery (Brandão \& Rego 1998, 9).

At first, people started going to this cave because they found it quite beautiful, a real divine work. Then they decided to place an image of the Sacred Heart of Jesus inside it. Differently from what happened at other caves, the pilgrimage was not a result of any appearance of Jesus Christ, the Holly Mother of Jesus, a saint or a miracle. It started simply because the local population felt the urge to create a supernatural atmosphere to give their lives a reason to be.

In other words, the cave became a place that could free them from the suffering caused by the constant droughts or at least minimize it. Steil $(1998,36)$ calls attention to this phenomenon. Chapels located in wild areas and harsh environment become privileged places for religious pilgrimage and welcome travelers, the sick or adventurers who cross fields and semi-deserts, a context that empowers the recognition of these spaces as sacred spaces (Fig. 4).

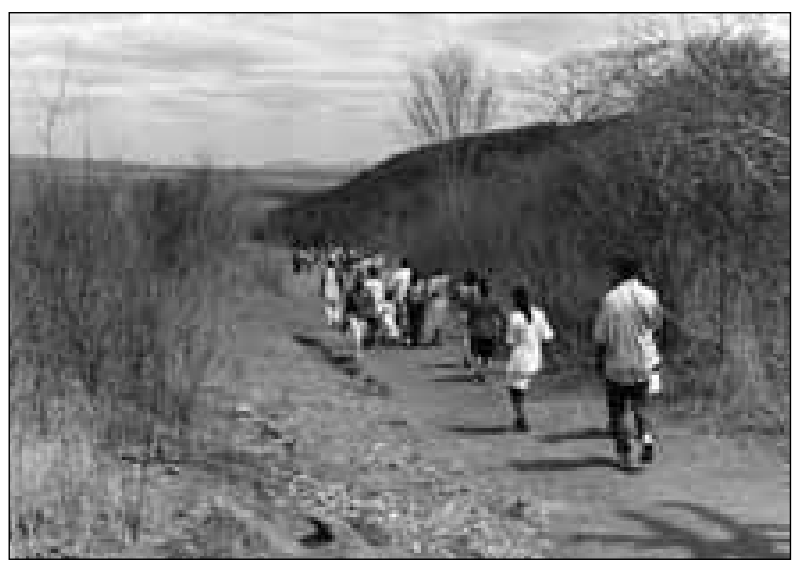

Fig 4: Pilgrims during their journey to the Patamuté Cave (photo: E.P. Barbosa). 


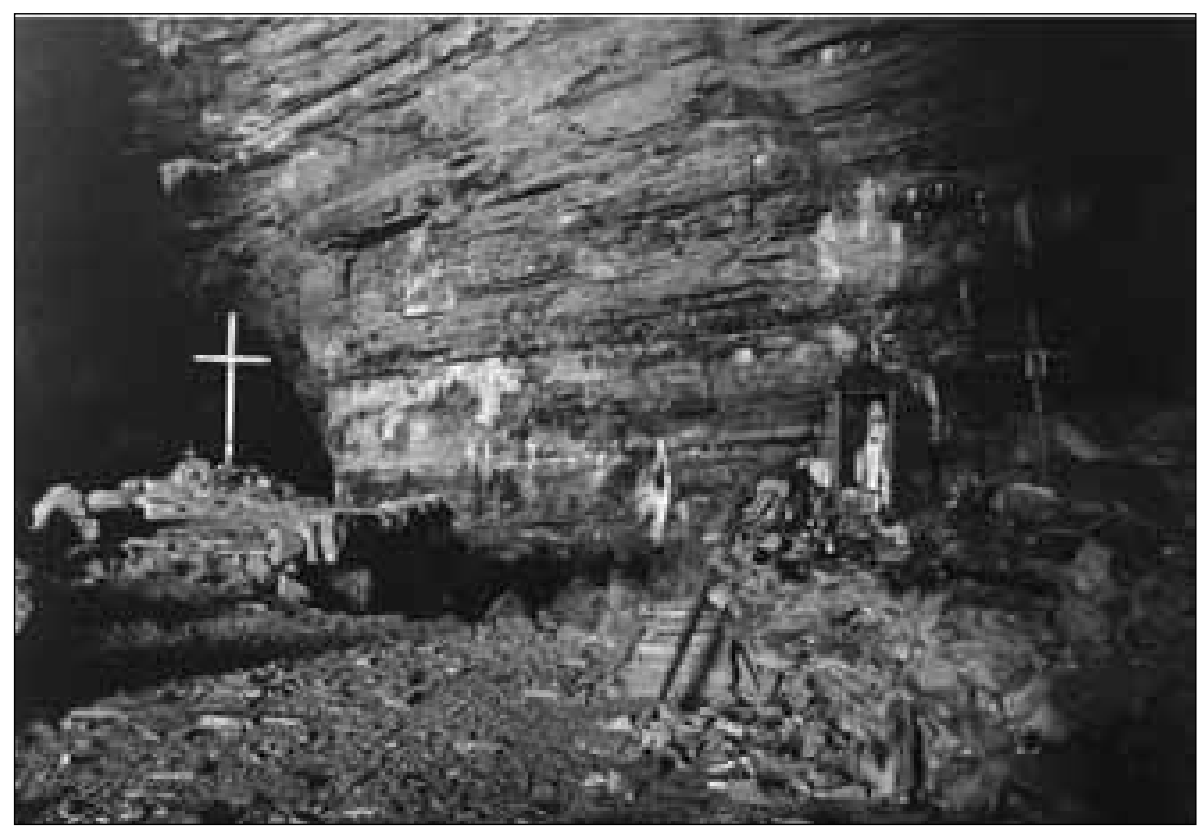

Fig 5: Religious objects inside the Lapa dos Brejões Cave (photo: E.P. Barbosa). too full, it would close and kill all pilgrims inside it.

The cave is presented as an appropriate place to meet the sacred since signs of religion are materialized in it and sacrifice, hope for better days, the return of Jesus and a place for penitence are the common beliefs associated to it.

These observations also apply to the pilgrimage that occurs annually to another cave, the Lapa dos Brejões (Fig. 5), located in the municipality of Morro do Chapéu. In the surroundings and in this cave, fireworks, processions, masses, weddings and baptisms happen during the festival of Our Lady, in

The mythical sense of the cave is present at all times and this feature starts with its location. The cave is on the top of a 50 meter-high hill, and the access to it is an irregular and steep path that adds to the pilgrims' suffering. This sacrifice is understood as a way to pay for the sins committed on a daily basis and become purified.

To Cipriano and Maltez $(1998,9)$, the characterization of the cave myth and its relationship with the fantastic is found in various ways, such as a prophecy attributed to Father Manoel Félix, predecessor of Father Toninho, who is said to have told people that if the "church" got the month of August. Like the Patamute pilgrimage, the Lapa dos Brejões festival occurs in an area which is away from a large urban center.

There are only 20 houses in the village called Brejão da Gruta, which is located within the Environmental Protected Area of Lapa dos Brejões Veredas do Romão Gramacho, at about $180 \mathrm{~km}$ from the municipality of Morro do Chapéu. As in Patamuté, the difficulties to access the area accentuate the feelings of grief and selfflagellation of pilgrims, as a sign of penitence to redeem their sins, as, according to the Bible, Jesus Christ did.

\section{DISCUSSIONS}

The existence of these religious symbols year after year characterizes the important roles that cave play in regional Brazilian societies. This could be translated in various ways, mainly into the sublimation of the sacred and the constant search for salvation as a way to ascend socially or give up committed sins. Since the sacrifice makes the body heavier and painful, the cave is seen as the meeting point between the pilgrim and the divine.

Another line of approach to the relationship between caves and local societies allows folk participation through the maintenance of its traditions and the resistance of the sertanejo (local country people) against the ideology imposed by large urban areas. These traditions based on a culture that is presented as apparently simple, carries a complex history of struggle and the overcoming of adversities encountered in the field by the common man.

These social religious behaviors can also be interpreted as a way to search for a strong identity that mixes various aspects of culture, expressed in a very unique symbolism. The persistence of the traditions is due mainly to the popular culture and the oral tradition found among the residents of these places. 


\section{CONCLUSIONS}

The universality of the belief that a picture placed inside a cave can promote miracles or bless a marriage, attract a legion of believers all around the world. Besides, a cave can fulfill roles not only as an underground cavity to be explored by speleologists but also as important cultural sites that should be studied, preserved and understood as an expression of local or regional traditions. Yet, these traditions should be kept alive regardless the new technologies or theoretical approaches. The cultural studies on caves and karst areas are important since they are places that fascinate mankind, and usually are not easily explained by common people.

This paper is not intended to diminish the physical studies of karst areas but it wants to emphasise the importance of the human variable, especially in developing countries, for the relationship between karst and caves in the popular tradition, transmitted by means of oral stories and folk beliefs goes beyond the scientific advances.

\section{ACKNOWLEDGMENTS}

Thanks to Lucília Panisset Travassos, for helping the authors with the final English revision.

\section{REFERENCES}

Alighieri, D., 2003: A divina comédia.- Nova Cultural, p. 430, São Paulo.

Brandão, J. R. \& Rêgo, L. F., 1999: A gruta do sagrado coração de Jesus de Patamuté e outras informações sobre Curaçá. Interview given to the UESC Speleological Group. Curaçá, 05 mar. 1999.

Campbell, J., 1994: As máscaras de Deus: mitologia oriental.- Palas Athena, p. 448, São Paulo.

Commelin, P., 1993: Mitologia grega e romana.- Martins Fontes, p. 448, São Paulo.

Cipriano, C. A. C. \& Maltez, T., 1998: Romaria do sagrado coração de Jesus da gruta de Patamuté: melhoria da infra-estrutura.- Prefeitura Municipal de Curaçá/SEBRAE-BA, Curaçá, Bahia.
Pimentel, J. M. O., Santos, B. S., Brazileiro, A. C., Lopes, A. P. S., Smith, G. \& Müller, A., 1999: Topografia da gruta de Patamuté. Proceedings of the $25^{\text {th }}$ Congresso Brasileiro de Espeleologia, Vinhedo/São Paulo.

Sampaio, T., 2002: O rio São Francisco e a Chapada Diamantina.- Companhia das Letras, p. 352, São Paulo.

Steil, C., 1998: As peregrinações no sertão: viajantes, enfermos e aventureiros cruzam campos, desertos e sertões em clima de religiosidade, festa e penitência- Ciência Hoje, 24, 142, 32-39, São Paulo. 